\title{
IMPACT OF DIETARY RESTRICTION ON FOLLICULAR WAVES IN CATTLE WITH PARTICULAR REFERENCE TO ANOESTRUS
}

\author{
M. M. R. Howlader' ${ }^{1}$ M. M. I. Hasan ${ }^{1}$, M. Atikuzzaman' ${ }^{2}$ S. Paul ${ }^{3}$ and S. Begum ${ }^{1 *}$
}

${ }^{1}$ Department of Physiology, ${ }^{2}$ Department of Theriogenology and Surgery, ${ }^{3}$ Department of Epidemiology and Public Health, Sylhet Agricultural University, Sylhet-3100, Bangladesh.

\begin{abstract}
Reproductive failure (anoestrus) is a one of the major problem in cattle production of Bangladesh due to under feeding and unavailability of balanced ration. This study was conducted for a period from July 2009 to June 2010 to determine the nutritional impact on the follicular growth using blood hormone assays and the rate of anoestrus in cows following dietary restriction and to develop a feasible feeding technique concerning the available feed ingredients in local market. A uniform group of 2-3 years old 15 heifers were selected and were grouped randomly into three named $\mathrm{T}_{1}(60 \%$ feeding restriction), $\mathrm{T}_{2}\left(40 \%\right.$ feeding restriction) and $\mathrm{T}_{3}$ (standard feeding). Body condition score (BCS) and body weight were measured by standard method. Hormonal assays were analyzed to determine the impacts of restricted feeding on the ovarian follicular cycle using blood sera. The average BCS and body weight was decreased significantly $(\mathrm{p}<0.01)$ in the animals of $\mathrm{T}_{1}$ and $\mathrm{T}_{2}$ compared to control $\mathrm{T}_{0}$. The average values of estrogen and progestrogen was decreased significantly $(\mathrm{p}<0.01)$ in restricted feeding heifers $\left(\mathrm{T}_{1} \& \mathrm{~T}_{2}\right)$ than that of standard feeding heifers $\left(\mathrm{T}_{3}\right)$. About $50 \%$ heifers showed irregular estrus and $50 \%$ showed anoestrus signs in the animals of $\mathrm{T}_{1}$ group. In addition, a total of $60 \%$ animals showed irregular estrus and $40 \%$ showed anoestrus condition in animals of $\mathrm{T}_{2}$ group. On the other hand, the animals of control group showed regular estrous cycle with good hormonal assays. Standard feeding could improve the cattle production efficiency by overcoming the reproductive failure using available feed ingredients.
\end{abstract}

Keywords: Nutrition, follicular waves, anoestrous, heifers, restricted feeding.

\section{INTRODUCTION}

Nutrition is one of the most important factors which have many adverse effects on estrus and ovarian cycles in cows. Underfeeding or overfeeding heifers have significant consequences on their development. Under feeding may result in sub-normal conception rate, underdeveloped mammary glands, and greater incidence of calving problems (Petterson et al., 1992). Overfeeding often results in weak expression of estrus, sub-normal conception rate, high embryonic mortality, decreases mammary gland development and reduced milk production (Murphy et al., 1991). Correlation between body weight gain and age at puberty indicate that increased growth rate of heifers results in younger age at puberty (Oyedipe et al., 1982). In Bangladesh major problems in dairy and beef cows are poor conception rate, early embryonic death, irregular cycles and failure of animals to return in heat (Shamsuddin, 1995). Throughout the bovine estrous cycle, follicular development progress in waves was determined by blood serum hormone assay. Follicular growth in cows occurs either in two (Ginther et al., 1989a, b) or three waves (Savio et al., 1988, Sirois and Fortune, 1988). In Bangladesh, dairy animals in most of the dairy farms represent low fertility, weak and insignificant heat, conception failure and repeat breeding which are the common cases (Hossain et al., 2001). Inadequate nutrition and underfeeding might have contribution on reproductive parameters. Little works on the effects of under nutrition and/or restricted nutrition on cow's estrous cycles/waves have been conducted so far throughout the world and limited work has been conducted in Bangladesh. For efficient dairy production management system, the knowledge of nutritional effects on the estrous cycle or ovarian cyclicity is essential. To develop a scientific knowledge for better and efficient dairy management and feeding strategies, the research work was designed and undertaken.

\section{MATERIALS AND METHODS}

\section{Study period and site}

The study was conducted from July 2009 to June 2010 in Sylhet Govt. district dairy farm, Sylhet, Bangladesh.

*Corresponding e-mail address: begumbd78@yahoo.com 


\section{M. R. Howlader and others}

\section{Experimental animals}

A uniform group of 21 heifers was selected initially from which 15 animals were used in this experiment. They were selected randomly from the herd and were numbered numerically. All the animals were born and reared under same farming condition. The BCS scale was measured from 1 to 5 . All the experimental heifers were fed allowing the standard Thumb rule of feeding system (Banergee, 1998) to raise their BCS up to 4.0. After reaching the BCS, 15 animals were selected and were grouped into three treatment groups- $\mathrm{T}_{1}(60 \%$ restricted feeding), $\mathrm{T}_{2}$ (40\% restricted feeding) and $\mathrm{T}_{3}$ (Standard feeding considerd as control group). Initially all the animals were treated with 4 fortnightly concurrent doses of Levamizole hydrochloride ( $7.7 \mathrm{mg}$ per $\mathrm{kg}$ body weight), albendazole ( $7.5 \mathrm{mg}$ per $\mathrm{kg}$ body weight), Fenbendazole (10 $\mathrm{mg}$ per $\mathrm{kg}$ body weight) and Ivermectin (0.2 $\mu$ g per kg body weight).

Table 1. Standard concentrate feed used in the experiment

\begin{tabular}{clcc}
\hline SL & Feed Ingredients & Quantity (in grams) & Composition $\%$ \\
\hline 1. & Corn & 750 & 25 \\
2. & Wheat bran & 600 & 20 \\
3. & Rice polish & 450 & 15 \\
4. & Khesari & 600 & 20 \\
5. & Soya bean meal & 510 & 17 \\
6 & DCP & 60 & 2 \\
7. & Salt & 30 & 1 \\
\hline \multicolumn{2}{r}{ Total } & $3000 \mathrm{~g}(3 \mathrm{~kg})$ & 100 \\
\hline
\end{tabular}

\section{Feeding management before restricted feeding}

Napier grass (Pennisetum purpureum) and para grass (Bracharia mutica) were fed to fulfill the dry matter requirement of the animals. The grass has been provided to all animals followed by the instructions given by Banerjee (1998). A concentrate mixture was given daily to all animals following the thumb rule methods of Banerjee (1998). The ingredients of mixed concentrate feeds were procured from the open market at Sylhet of Bangladesh. Water was made available to each animal for $24 \mathrm{hrs}$.

\section{Feeding management during restricted feeding}

Napier grass (Pennisetum purpureum) and para grass (Brachariamutica) were made available to satisfy the dry matter requirement of the animals. The grasses were provided to animals of $\mathrm{T}_{3}$ group following the instructions given by Banerjee (1998). The animals in $\mathrm{T}_{1}$ and $\mathrm{T}_{2}$ were restricted by $60 \%$ and $40 \%$ green grass, respectively. Similarly, three concentrate mixtures were given daily to animals in age as $60 \%$ in $\mathrm{T}_{1}, 40 \%$ in $\mathrm{T}_{2}$ and $0 \%$ in $\mathrm{T}_{3}$ groups, respectively. The ingredients of mixed concentrate feeds were procured from the local market of Sylhet in Bangladesh. Ad libitum water was supplied available to each animal at all times.

\section{Ultrasound imaging}

The ovarian follicles were monitored regularly by using ultrasonography machine (Easy-scan ${ }^{\mathrm{TM}}$ curve bovine ultrasound machine, BCF technology, UK).

\section{Collection of blood sample and analysis}

Blood was collected every 3 days interval by jugular venepuncture. Samples were kept at room temperature for $1 \mathrm{~h}$, and at $4{ }^{\circ} \mathrm{C}$ for $24 \mathrm{~h}$. Serum was collected before being centrifuged at $3000 \mathrm{rpm}$ for 10 minutes and stored at $-20^{\circ} \mathrm{C}$ until assayed for estrogen and progesterone concentrations using ELISA kit.

\section{Determination of hormone concentration}

Progesterone concentrations in blood serum were determined through solid phase competitive ELISA by using commercially available kit (Bio Check, Inc. USA, Lot. RN-28387) (Ali et al., 2009). The sensitivity of the progesterone ELISA assay was $0.3 \mathrm{ug} / \mathrm{ml}$, intra-assay precision was less than $7.1 \%$ and inter-assay precision was less than $12.6 \%$. Estradiol $17-\beta$ concentrations in blood serum were determined through ELISA by using 
commercially available kit (Bio Check, Inc. USA, Lot. RN-27637). The sensitivity of the estradiol ELISA assay was $10 \mathrm{pg} / \mathrm{ml}$, intra-assay precision was less than $24.1 \%$ and interassay precision was less than $26.7 \%$.

\section{Statistical analysis}

The collected data were analyzed statistically through analysis of variance, using completely randomized design. Significant means were compared using Duncan's Multiple Range (DMR) test (Steel and Torrie, 1990). The obtained data in two years of experiment were statistically analyzed in the laboratory using standard methods.

\section{RESULTS}

The experiment was started by selecting 15 heifers bearing same age and the body condition score (BCS) having an average of 3.5. The animals of $\mathrm{T}_{1}$ group were fed subsequent restriction up to $60 \%$, animals in $\mathrm{T}_{2}$ were fed with $40 \%$ restricted feeding and animals in $\mathrm{T}_{3}$ group were fed by standard feeding named control group i.e. no restriction to feed (standard feeding). Afterwards the restriction feeding, the BCS of $\mathrm{T}_{1}, \mathrm{~T}_{2}$ and $\mathrm{T}_{3}$ heifers were shown $2.43 \pm 0.09,3.58 \pm 0.09$ and $3.98 \pm 0.06$ after completion of first year and were shown $2.54 \pm 0.08,3.65 \pm$ 0.09 and $4.15 \pm 0.05$ after completion of second year of experiment, respectively (Table 2 and 3 , respectively). The ultrasonography was performed to all experimental animals in every three days intervals. The ultrasonography results of restricted feeding animals were found unclear due to irregular estrus or anoestrus condition but follicular growth of control group were found good.

Table 2. Feeding and BCS after completion of first year of the experiment

\begin{tabular}{|c|c|c|c|c|}
\hline \multicolumn{2}{|c|}{ ITEM } & ${ }^{1}$ Treatment-1 $\left(\mathrm{T}_{1}\right)$ & ${ }^{2}$ Treatment-2 $\left(\mathrm{T}_{2}\right)$ & ${ }^{3}$ Treatment-3 (Control, $\left.\mathrm{T}_{3}\right)$ \\
\hline \multirow[t]{2}{*}{ Feed/Animal/Day } & Green Grass & $3.2 \mathrm{~kg}$ & $4.8 \mathrm{~kg}$ & $8 \mathrm{~kg}$ \\
\hline & Concentrate & $1.2 \mathrm{~kg}$ & $1.8 \mathrm{~kg}$ & $3 \mathrm{~kg}$ \\
\hline \multicolumn{2}{|c|}{ Percent of restriction of feeding } & $60 \%$ less & $40 \%$ less & 0 \\
\hline \multicolumn{2}{|c|}{$\begin{array}{l}\text { Body Condition Score (1-5 Scale) (Mean } \\
\text { SD/SE) }\end{array}$} & $2.43 \pm 0.09 * *$ & $3.58 \pm 0.09 * *$ & $3.98 \pm 0.06$ \\
\hline \multicolumn{2}{|c|}{ Body weight (kg) (Mean SE/SD) } & $136.28 \pm 2.81 * *$ & $161.13 \pm 2.81 * *$ & $186.10 \pm 1.99$ \\
\hline
\end{tabular}

Table 3. Feeding and BCS after completion of second year of the experiment

\begin{tabular}{|c|c|c|c|c|}
\hline \multicolumn{2}{|c|}{ ITEM } & ${ }^{1}$ Treatment-1 $\left(\mathrm{T}_{1}\right)$ & ${ }^{2}$ Treatment-2 $\left(\mathrm{T}_{2}\right)$ & ${ }^{3}$ Treatment-3 (Control) $\left(\mathrm{T}_{3}\right)$ \\
\hline \multirow[t]{2}{*}{ Feed/Animal/Day } & Green Grass & $3.2 \mathrm{~kg}$ & $4.8 \mathrm{~kg}$ & $8 \mathrm{~kg}$ \\
\hline & Concentrate & $1.2 \mathrm{~kg}$ & $1.8 \mathrm{~kg}$ & $3 \mathrm{~kg}$ \\
\hline \multicolumn{2}{|c|}{ Percent of restriction of feeding } & $60 \%$ & $40 \%$ & 0 \\
\hline \multicolumn{2}{|c|}{ Body Condition Score (1-5 Scale) } & $2.54 \pm 0.08 * *$ & $3.65 \pm 0.09 * *$ & $4.15 \pm 0.05 * *$ \\
\hline \multicolumn{2}{|l|}{ Body weight (kg) } & $132.16 \pm 2.16^{* *}$ & $155.35 \pm 2.55 * *$ & $178.15 \pm 1.86^{* *}$ \\
\hline
\end{tabular}

Heifers in group of $T_{1}, T_{2}$ showed significantly $(\mathrm{P}<0.01)$ decrease values of estrogen (Table 4$)$ such as $178.65 \pm 6.13$ and $184.83 \pm 7.18 \mathrm{pg} / \mathrm{ml}$, respectively, compared to control group (197.65 \pm 5.91$)$. Where as the average progesterone values of $\mathrm{T}_{1}, \mathrm{~T}_{2}$ were decreased significantly $(\mathrm{P}<0.01)$ which was $0.40 \pm 0.12,0.34 \pm 0.11$ respectively in contrast to control group $\mathrm{T} 3(0.28 \pm 0.11)$. From the hormonal analysis it was concluded that the animals of treatment groups $\mathrm{T}_{3}$ group perform better and showed more regular estrous or heat than $\mathrm{T} 1$ and $\mathrm{T} 2$ groups (Table 4) i.e. the standard feeding would be helpful for normal follicular growth and for showing regular estrus cycle. 


\section{M. R. Howlader and others}

Table 4. Estrus cycle and average hormonal status of heifers

\begin{tabular}{llll}
\hline Parameters & \multicolumn{1}{c}{${ }^{1}$ Treatment-1 $\left(\mathrm{T}_{1}\right)$} & \multicolumn{1}{c}{${ }^{2}$ Treatment-2 $\left(\mathrm{T}_{2}\right)$} & ${ }^{3}$ Treatment-3 $\left(\mathrm{T}_{3}\right)(\mathrm{control})$ \\
\hline Estrogen $(\mathrm{pg} / \mathrm{ml})$ & $178.65 \pm 6.13^{* *}$ & $184.83 \pm 7.18^{* *}$ & $197.65 \pm 5.91$ \\
Progesterone $(\mathrm{ng} / \mathrm{ml})$ & $0.40 \pm 0.12^{* *}$ & $0.34 \pm 0.11 * *$ & $0.28 \pm 0.11$ \\
Estrus cycle & Irregular $(50 \%$ Heifers $)$, & Irregular $(60 \%$ Heifers $)$, & Regular $(100 \%$ Heifers $)$ \\
& Anoestrus $(50 \%)$ & Anoestrus $(40 \%)$ & \\
\hline
\end{tabular}

${ }^{, 2,3}$ Average of five replications, $* *$ Significant $(\mathrm{P}<0.01)$ at $95 \% \mathrm{CI}$

\section{DISCUSSION}

Daily nutritional requirement of cross-breed heifers are very important to develop and keeping functioning of all the vital organs. In our present study we have developed a standard feeding practice using locally available feed ingredients followed by the instruction of Banergee (1998) to maintain the reproductive efficiency of heifers. Feeding restriction of heifers was caused a reduced BCS and developed a gradual of anoestrus in experimental heifers. Nutritional deficiency causes a reduce muscular activity with gonadotrophin depression. In this study, the feeding restriction was reduced the body weight as well as body condition score (BCS) in the heifers. Earlier researcher was reported that supplementation of different feed ingredients increase the live weight of animals. Lindt and Blum (1994) who reported that the carcass yield of calves increased by supplementation of iron with dietary feeds. Similarly, Vatn and Framstad (2000), Vellema et al. (1997) reported that cobalt increases live weight in sheep. So, the standard feeding to heifers could be able to improve the body physiology as well as body weight.

In our study we found that the heifers with restricted feeding were developed an irregular estrus followed by anestrus condition. On the other hand, the heifers of standard feeding showed regular estrus cycle with remarkable gonadotrophin secretions. This finding is partially similar to that finding of Wiltbank et al. (1962). They reported that a greater proportion of cows was failed to show estrus due to low energy level after calving. Underfeeding delays puberty in heifers (Joubert, 1954) and stops estrus and ovarian cyclicity in heifers that are already cyclic (Terqui et al., 1982). Nutritional restriction has got immediate negative effects on follicular growth and cyclicity (Mackey et al., 1997; 1998; 1999). The dietary energy restriction might influence the LH release directly at the pituitary level as well as indirectly through effects on ovarian steroid production (Beal et $a l ., 1978)$. The energy restriction decreased the incidence of heifers having estrous cycles and the anestrous heifers did not respond to a progestin-estrogen treatment for induction of estrus (Imakawa et al., 1986). Cessation of ovulation observed in nutritionally induced beef heifers by Bossis et al. (1999). LH secretion is inhibited by E2 in the nutritionally anestrous heifer and is accepted following supplementation of high energy diet (Imakawa et al., 1984). Energy intake has influenced on a wide variety of endocrine, neural and metabolic mechanisms (Rhodes et al., 1996) viz. changes of gonadotropic hormone secretion from the pituitary, production of progesterone during both the estrous cycle and pregnancy, differential sensitivity of the pituitary-hypothalamus to steroids and releasing hormones and changes in ovarian activity measured by hormone secretion, follicular development and ovulation (Short and Adams, 1988). Less feeding reduces all the functional activities of the body like as growth and reproduction.

\section{CONCLUSION}

The study demonstrates that the restricted dietary feeding poses to reduce the average body weight and the estrogen values along with low progestogen. Therefore, animals provided with standard feeds using locally available feed ingredients could perform equally in respect to reproductive hormone production like estrogen and progesterone with regular estrus cycle.

\section{ACKNOWLEDGEMENT}

The authors are grateful to the Bangladesh Agricultural Research Council (BARC) for funding of this research work and the authority of Sylhet Govt. Dairy Farm to allow to samples from their heifers for this study. 
Impact of dietary restriction on follicular waves in cattle

\section{REFERENCES}

1. Ali MA, Lodhi LA, Ahmad I and Younas M (2009). Serum progesterone and estradiol-17 $\beta$ profiles in nili ravi buffaloes (Bubalus bubalis) with and without retention of fetal membranes. Pakistan Veterinary Journal 29: 64-66.

2. Banerjee GC (1998). Feeding cattle and buffaloes by thumb rule method. A Text Book of Animal Husbandry. Eighth Edition. pp. 669-677.

3. Beal WE, Short RE, Staigmiller RB, Bellows RA, Kaltenbach CC and Dunn TG (1978). Influence of dietary energy intake on bovine pituitary and luteal function. Journal of Animal Science 46: 181-188.

4. Bossis I, Welty SD, Wettemann RP, Vizcarra JA, Spicer LJ and Diskin MG (1999). Nutritionally induced an ovulation in beef heifers: ovarian and endocrine function preceding cessation of ovulation. Journal of Animal Science 77: 1536-1546.

5. Ginther OJ, Kastelic JP and Knopf L (1989a). Composition and characteristics of follicular waves during the bovine estrous cycle. Animal Reproduction Science 20: 187.

6. Ginther OJ, Kastelic JP and Knopf L (1989b). Temporal associations among follicular waves. Journal of Reproduction and Fertility 87: 223.

7. Hossain MK, Hossein MS, Bari FY, Shamsuddin M and Paul RK (2001). Economics of fertility management of small holding dairy farms. The Bangladesh Veterinarian 18: 83-88.

8. Imakawa K, Day ML, Garcia-Winder M, Zalesky DD, Kittok RJ, Schanbacher BD and Kinder JE (1986). Endocrine changes during restoration of estrous cycles following induction of anestrus by restricted nutrient intake in beef heifers. Journal of Animal Science 63: 565-571.

9. Imakawa K, Kittokand RJ and Kinder JE (1984). Luteinizing hormone secretion after withdrawal of exogenous progestogen in heifers fed three levels of dietary energy. Journal of Animal Science 58: 151-158.

10. Joubert DM (1954). The influence of high and low nutritional planes on the oestrus cycle and conception rate of heifers. Journal of Agricultural Science 45: 164-172.

11. Lindt F and Blum JW (1994). Growth performance, haematogical traits, meat variables, and effects of treadmill and transport stress in veal calves supplied different amounts of iron. Zentralblatt fürVeterinärmedizin Reihe A 41: 333342.

12. Mackey DR, Sreenan JM, Roche JF and Diskin MG (1997). The effect of acute changes in energy intake on follicle wave turnover in beef heifers. Irish Veterinary Journal 50: 366.

13. Mackey DR, Sreenan JM, Roche JF and Diskin MG (1998). The effect of acute changes in nutritional intake on plasma steroid concentrations in beef heifers. Proceedings of the Association of Veterinary Teachers and research Workers, Spring Scientific Meeting, Veterinary Research Laboratory. Abbottstown, Co. Dublin, $11^{\text {th }}$ March, 1998.

14. Mackey DR, Sreenan JM, Roche JF and Diskin MG (1999). The effect of acute nutritional restriction on incidence of anovulation and periovulatoryoestradiol and gonadotropin concentrations in beef heifers. Biology of Reproduction 61: 1601-1607.

15. Murphy MG, Enright WJ, Crowe McConnell K, Spicer LJ, Boland MP and Roche JF (1991). Effect of dietary intake on pattern of growth of dominant follicles during the estrous cycle in beef heifers. Journal of Reproduction and Fertility 92: 333-338.

16. Oyedipe EO, Osori DIK, Kerejola OA and Saror D (1982). Effects of level of nutrition on onset of puberty and conception rates of zebu heifers. Theriogenology 18: 525-539.

17. Petterson DJ, Perry RC, Kiracofe GH, Bellows RA, Staigmiller RB and Corah LR (1992). Management considerations in heifer development and puberty. Journal of Animal Science 70: 4018-4035.

18. Rhodes FM, K W Entwistle, J E Kinder, 1996. Changes in ovarian function and gonadotropin secretion preceding the onset of nutritionally induced anestrus in Bosindicusheifers. Biol Reprod; 55:1437-1443.

19. Savio JD, Keenan L, Boland MP and Roche JF (1988). Pattern of growth of dominant follicles during the estrous cycle in heifers. Journal of Reproduction and Fertility 83: 663.

20. Shamsuddin M (1995). Fertility trends and status of estrus detection in the bovine farm condition in Bangladesh. The Bangladesh Veterinary Journal 29: 9-16.

21. Short RE and Adams DC (1988). Nutritional and hormonal interrelationships in beef cattle reproduction. Canadian Journal of Animal Science 68: 29-39.

22. Sirois J and Fortune JE (1988). Ovarian follicular dynamics during the estrous cycle in heifers monitored by realtime ultrasonography. Biology of Reproduction 39: 308-317.

23. Steel RGD and Torrie JH (1990). Principles and Procedures of Statistics. 2nd Ed., McGraw Hill Book Co. Inc., New York, USA. 


\section{M. R. Howlader and others}

24. Terqui M, Chupin D, Gauthier D, Perez N, Pelot J and Mauleon P (1982). Influence of management and nutrition on postpartum endocrine function and ovarian activity in cows. In: H Karg and E Schallenberger (eds), Factors influencing fertility in the postpartum cow. Martinus Nijhoff, the Hague, the Netherlands. pp. 384-408.

25. Vatn and Framstad (2000). Anaemia in Housed Lambs: Effects of Oral Iron on Clinical Pathology and Performance. Acta Veterinaria Scandinavica 41: 273-81.

26. Vellema P, Moll L, Barkema HW and Schukkan YH (1997). Effect of cobalt supplementation on serum vitamin B12 levels, weight gain and survival rate in lambs grazing on cobalt deficient pastures, Veterinary Quarterly 19: 01-05.

27. Wiltbank JN, WRowden W, Ingalls JE, Gregory KE and Koch RM (1962). Effect of energy level on reproductive phenomena of mature Hereford cows. Journal of Animal Science 21: 219-225. 